\title{
Tros- og livssynsdialog i konfirmasjonsundervisning
}

\section{Av Rosemarie Rustad Stakston}

Denne artikkelen undersøker hvordan ungdom larer tros- og livssynsdialog på en konfirmasjonssamling. Artikkelen byggerpåobservasjon avøvelserbruktpå en konfirmasjonssamling, og finner at ungdom larer tros-og livssynsdialog gjennom motsetningsfylte praksiser som kan føre til endringsprosesser.

Rosemarie Rustad StaKston, f. 1993, sokneprest Fåberg, Midtbygdsvegen 57, 2636 Øyer,
E-post:rosemarie.r.stakston@gmail.com

\section{INTRODUKSJON}

Hvordan lærer ungdom tros- og livssynsdialog på en konfirmasjonssamling?1. Dette er problemstillingen og spørsmålet jeg vil undersøke i denne artikkelen. Jeg analyserer en konfirmasjonssamling ved hjelp av tre læringsteorier. Analysen er tredelt og ser på læring på individuelt, kollektivt og institusjonelt nivå. Min teoretiske interesse har vært å unders $\emptyset$ ke fenomenet med tanke på læring.

$\AA$ ha dialog hvor samtalen tar opp tro og livssyn, kan se ut til å bli stadig mer aktuelt i vårt flerkulturelle og flerreligiøse samfunn. Dette er noe som har innvirkning også i «kirkenorge» og Den norske kirke. Fra øvre hold i Den norske kirke har det de siste årene blitt tydelig at det er et $\emptyset$ nske om at menigheter skal drive dialogarbeid, og da kanskje spesielt knyttet til trosopplæringen i menigheten. Dette er med på å gi denne artikkelen høy aktualitet for kirken og kirkens trosopplæring i dag.

Noe som bidrar til å gjøre mitt bidrag ytterligere aktuelt, er at noen øvelser fra konfirmasjonssamlingen jeg studerer, er hentet fra: «Homo, hore, jøde, terrorist, svarting» - sier vi. Et ressursmateriell om antisemittisme, muslimfiendtlighet og rasisme mot rom til bruk $i$ Den norske kirke (heretter forkortet til «Sier vi»). Dette er et ressursmateriell (og hefte) utarbeidet av Kirkelig dialogsenter i Oslo og utgitt av Mellomkirkelig råd. Materiellet ble først utgitt i 2013 og ble opprinnelig utviklet for de som driver og underviser trosopplæring. Etter utgivelsen ble materiellet tatt i bruk av menigheter og i andre sammenhenger. I $2018 \mathrm{kom} \mathrm{det}$ en revidert utgave av «Sier vi» (《Sier vi» 2018:4-5).

Jeg observerte og gjorde notater og lydopptak av en konfirmasjonssamling hvor blant annet $\emptyset$ velser fra «Sier vi» ble tatt i bruk. Notatene og lydopptaket fra denne samlingen er materialet for analysen.

1 Denne artikkelen er en forkortelse og omgjøring av fordypningsoppgaven min i teologi, hvor førsteamanuensis Elisabeth Tveito Johnsen var veileder. 


\section{TEORI}

Til materialet jeg har etablert, vil jeg bruke tre teoretiske perspektiver på læring av ulike samtidspedagoger.

\section{Læring som eksistensiell prosess}

Teorien til Peter Jarvis om læring som eksistensiell prosess er det første perspektivet. Jarvis tenker seg læring som et eksistensielt fenomen hvor utgangspunktet er det hele mennesket med kropp og sinn. Læring forstås som et eksistensielt fenomen, et livslangt identitetsprosjekt. «Learning to be me» - kaller Jarvis det. Samtidig som dette er et individuelt prosjekt, så er en forståelse av hele mennesket $\mathrm{i}$ en sosial situasjon fundamentalt for denne forståelsen av læring. Den er altså samfunnsmessig betinget: «Learning to be me in society» (Jarvis 2009:30).

Jarvis sin teori om læring som en livslang eksistensiell prosess, tar utgangspunkt i at mennesker stadig lærer og stadig forandrer seg. I «learning to be me» er tanken hans at læring handler om «being» og «be-coming»; «gjennom læring er jeg - og blir jeg meg». Læring innebærer bevegelse og forandring, og som tidligere nevnt tenker Jarvis at læring som eksistensiell prosess skjer gjennom erfaringer som fører til forandring og får en til å utvikle seg som menneske. Dette skjer når erfaringer bringer med seg disharmoni og ubalanse, som skaper det Jarvis kaller «disjunction». Denne uoverensstemmelsen, eller mangelen på sammenheng, skaper mulighet for forandring. Ved å på et aller annet vis gi mening til erfaringen blir uoverensstemmelsen (《 the disjunction») løst. Erfaringen fører slik til en forandring, dette er læring som en eksistensiell endringsprosess (Afdal 2013:103-105, Jarvis 2009:26-27).

\section{Læring som praksisfellesskap}

Den neste læringsteorien er Jean Lave og Etienne Wenger sitt perspektiv på læring som praksis. De tar i sin læringsteori avstand fra den tradisjonelle måten å tenke læring på som bare en kognitiv prosess, og fokuserer mer på et praksisperspektiv (Wenger 2009:209).

I boken Situated Learning er noe av hovedpoenget til Lave og Wenger at læring er et aspekt ved alle sosiale praksiser og ikke en avgrenset aktivitet. De tenker altså på læring som noe som like mye skjer utenfor skole og undervisning. Sosiale praksiser kan være yrke, fritidsaktiviteter og trossamfunn. Sosiale praksiser læres ved å delta, tanken er praksiser som det som læres. Lave og Wenger tar utgangspunkt i studier av læring i ulike sosiale praksiser, det være seg jordmødre, skreddere eller medlemmer i Anonyme Alkoholikere. Det som er felles er at læring i disse eksemplene er en form for mesterlære. En sosial og kollektiv mesterlære som handler om forholdet mellom lærlingen og en sosial 
praksis. Læring beskrives som en forandring i deltagerposisjonen i praksisen. Tanken går ut på at man starter i periferien av en praksis, for så å jobbe seg innover mot dens sentrum. Ved å delta i praksisfellesskapet vil de lærende gradvis tilegne seg kunnskaper og mestre ferdigheter, og ved det bevege seg fra en posisjon i ytterkanten til å bli sentrale aktører (Afdal 2013:174-176). Legitim perifer deltagelse er et begrep som Jean Lave og Etienne Wenger kommer med i boken Situated Learning. Legitimate peripheral participation. Legitim perifer deltagelse handler nettopp om dette med å delta i et praksisfellesskap og bevege seg fra periferien til dets sentrum, og om å lære ferdigheter i en sosial praksis (Afdal 2013:175).

\section{Ekspansiv læring}

Det siste perspektivet er Yrjö Engeström sin teori om ekspansiv læring («expansive learning»). Engeström skriver at standard læringsteorier er fokusert på prosessen hvor et subjekt tilegner seg gjenkjennbar kunnskap eller ferdigheter. Disse ferdighetene eller kunnskapen forstås som veldefinerte og stabile. Problemet er at læring ofte ikke foregår slik som disse teoriene legger det fram. Mennesker og organisasjoner må hele tiden lære ting som er udefinerte og ustabile. Vi må lære nye former for aktiviteter som ikke finnes ennå. Disse aktivitetene blir rett og slett lært mens de blir skapt. Engeström mener at standard læringsteorier har lite å komme med om man ønsker å forstå disse prosessene (Engeström 2009:58).

Med sin teori om ekspansiv læring forstår altså Engeström læring ikke bare som når mennesker blir lært inn i eksisterende kunnskaper og ferdigheter, men at læring kan være å skape nye kunnskaper og ferdigheter sammen. Ekspansjonen skjer ikke uten videre av seg selv. En konkret ekspansjon kan være å ta inn nye redskaper eller nye subjekter inn i en aktivitet, eller å bruke gamle redskaper på en ny måte. Ekspansjonen skjer som et resultat av at aktiviteter og mennesker snakker og handler sammen. Gjennom ekspansjon ligger det muligheter for ny kunnskap, i videste forstand nye måter å handle og forstå på. (Afdal 2013:191192). Dette kan man si er læring som skaping av kunnskap, også kalt kunnskaping. Kunnskaping har et innovativt aspekt. Kunnskaping betyr at kunnskap hele tiden gjøres ny, forandres og utvikles. Med kunnskaping er det like mye snakk om en væremåte som et produkt (Afdal 2013:199-200) .

\section{Tre perspektiver på tre nivåer}

De tre perspektivene som jeg bruker i min analyse er tre læringsteorier som kan sies å være perspektiver på ulike nivå, på individuelt, kollektivt og institusjonelt nivå. Jarvis sin teori og identitetsprosjekt kan sies å fokusere på individet. Selv om han vektlegger at teorien er samfunnsmessig betinget ved at man læres inn i 
en sosial situasjon, så er «learning to be me» allikevel et individuelt prosjekt, det vil si den enkeltes prosjekt med å finne ut hvem en er/vil være. Lave og Wenger sin teori om læring som praksisfellesskap løfter perspektivet fra å bare være på et individnivå til å analysere praksiser. Læringen går også fra å i hovedsak dreie seg om noe som skjer inni, og med ett menneske, til å dreie seg om å læres inn i en praksis/et praksisfellesskap. Denne læringsteorien kan slik sett beskrives til å være på et kollektivt nivå

Til slutt har vi Engeström sin teori om ekspansiv læring. Denne teorien kan brukes til å fokusere på et annet nivå igjen. I ekspansiv læring er ikke læring begrenset til at et individ tilegner seg noen eksiterende ferdigheter, og analyserer ikke læring på et individuelt nivå. Ekspansiv læring unders $\emptyset$ ker læring kollektivt ved å studere hvordan institusjoner lærer, og er egnet til en analyse på institusjonelt nivå. Når jeg i analysen min vil undersøke ekspansiv læring, vil jeg studere hvordan kirken ved å løse konfirmantundervisningen på nye måter kan utfordre eksisterende kunnskap og praksiser.

\section{Analyse}

Jeg observerte en konfirmasjonssamling med tros- og livssynsdialog som varte i to timer på kveldstid en ukedag. På den foregående konfirmantundervisningen hadde presten (som holdt samlingen) bedt konfirmantene om gjerne å ta med seg en venn med en annen tro eller et annet livssyn til å delta på den konfirmasjonsundervisningen jeg observerte. Det var elleve konfirmanter på samlingen, i tillegg var det to gjester/venner av konfirmantene med annen tro/ annet livssyn. Siden to av ungdommene som deltok på samlingen, ikke var konfirmanter, vil betegnelsen på alle sammen (konfirmantene og gjestene) videre være ungdommene. Samlingen hadde flere temaer og $\emptyset$ velser, hvor tros- og livssynsdialog lå implisitt i alt de gjorde. Jeg vil i hovedsak analysere én av $\emptyset$ velsene som de gjorde. Denne $\emptyset$ velsen er en $\emptyset$ velse hentet fra «Sier vi»-heftet. I «Sier vi» heter $\emptyset v e l s e n ~ « A v g i$ din stemme med føttene» («Sier vi» 2018:112-113). $\emptyset$ velsen foregikk ved at en prosjektor lyste opp et spørsmål med fire svaralternativer ( $\mathrm{A}, \mathrm{B}, \mathrm{C}, \mathrm{D})$ på veggen. Det var til sammen fem spørsmål. Ungdommene skulle for hvert spørsmål ta stilling til spørsmålet ved å gå til et av svaralternativene (hvert hjørne i den delen av rommet der de holdt til, var A, B, C og D).

\section{DEL 1: Læring på individuelt nivå}

«Avgi din stemme med føttene»-øvelsen - «learning to be a religious me». Innledningsvis gav presten en instruksjon på hva som var viktig i denne øvelsen:

Prest: Det som er viktig nå, er at alle tar utgangspunkt i seg selv. Her er det ingen som representerer noen andre, eller som skal snakke for andre. Dere som er gjester da, dere fär vere dere selv. Alle skal vare seg selv. Og det er best om man sier «Jeg tror at», eller 
«jeg tenker» og ikke «du mener», men at vi snakker ut fra oss selv, ikke sant? Det er viktig når vi jobber med dialog. Og så er det noen andre viktige retningslinjer, og det er å ha respekt for hverandre, og for at vi kan mene forskjellige ting, og det er greit. Og så er det viktig å ha tillit til at det som snakkes om her, det blir her, [...]. og det å vcere litt frimodig, og spørre om det er noe dere lurer på, det er også viktig. Tørre kanskje å si ting selv om det kanskje er litt skummelt. Vere litt åpne. Da blir det enda mer spennende. Så tenker jeg at det å ..., dialog det handler om å dele, ikke sant? Man må vcere sammen og prøve å forstå hverandre, [...].

Prestens innledningsord for $\emptyset$ velsen viser at det er et $\emptyset$ nske om at $\emptyset$ velsen skal få ungdommene til å være åpne om sine egne tanker og erfaringer. For å se om «ønsket ble oppfylt» vil jeg bruke et av spørsmålene fra øvelsen for å se på ungdommenes respons.

Spørsmålet med svaralternativer så slik ut:

Tror vi alle på samme Gud?

a Nei, Jesus er den som viser oss hvem Gud er: Vi kan ikke kjenne Gud uten å vite hvem Jesus er.

b Kanskje. Vi kan bare forholde oss til det vi vet, at Jesus er sannheten, veien og livet. Men Gud er mer enn hva vi ser og erfarer.

c Ja. Gud viser seg på forskjellige måter i de ulike religionene. Hadde jeg vært født i India hadde jeg kanskje vært hindu.

d Det betyr ikke noe for meg. Det viktigste er at vi lever godt sammen og gjør godt mot hverandre. («Sier vi» 2018:113)

Ordlyden i disse svaralternativene (med Jesus som utgangspunkt) viser at dette spørsmålet fra øvelsen $\mathrm{i}$ «Sier vi», i utgangpunktet er beregnet på grupper med kristen tilhørighet. Dette ble ikke kommentert eller problematisert hverken av presten eller ungdommene på samlingen. Da dette spørsmålet ble stilt, spredte ungdommene seg utover og det sto noen i hvert hjørne unntatt på $\mathrm{A}$, der sto det ingen. Her er et utdrag av samtalen mellom presten og ungdommene som fant sted etter at ungdommene hadde tatt stilling til spørsmålet. Først henvendte presten seg til ungdommene som hadde stilt seg på svaralternativ B:

Ungdom 1: Jeg tenker at kanskje alle religioner tenker på samme Gud. Så derfor valgte jeg «kanskje». Og vi bare må forholde oss til det, vi tror på en måte, ja liksom oppvokst, ja liksom B, C, D, litt sånn. (Peker på de ulike hjørnene)

Prest: Du er litt sånn mellom B, C og D?

Ungdom 1: Ja, ja.

Prest: Men du har tenkt på det? 
Ungdom 1: Ja, tenk om det er samme Gud? Det er forskjellig med hvor man har fătt det fra. I hvilket land man er, eller hvilket land man har vokst opp $i$.

Prest: Mmm, og da kunne du kanskje ha vært her? (viser til C-hjørnet). For her er jo de to gjestene våre, de har jo satt deg her på C: Ja, Gud viser seg på forskjellige måter. Hva var det som gjorde at dere valgte å sitte her?

Ungdom 2 (gjest): Hvis foreldrene mine var norske, så hadde jeg mest sannsynlig vart kristen jeg også. (Litt utydelig videre).

Prest: Så det er ikke bare landet, men foreldrene?

Ungdom 2 (gjest): Ja, eller kulturen og familien òg.

Prest: Ja, så familien har mye å si? Og dere som sitter her, syns ikke det betyr så mye, eller? (presten beveger seg bort mot de som sitter på $\mathrm{D}$ ).

Ungdom 3: (sier litt som blir utydelig ...) Man kan jo ha det godt selv om man ikke tror på Gud. Og hvis Gud gjør det bedre er det bare et pluss ... (litt for lavt og utydelig videre for lydopptakeren).

Utdraget viser at ungdommene følger opp prestens instruksjon om å være åpne og mene forskjellige ting, ved at de står på de ulike svaralternativene (unntatt A). Flere av ungdommene følger også opp det presten sa om å snakke ut ifra seg selv. For eksempel Ungdom 1, som er sitert over, formulerer seg med ord som «jeg tenker ...» og «derfor valgte jeg ...»».

Hva sier dette utdraget av ungdommenes respons oss i forhold til spørsmålet om læring som eksistensiell prosess? Jeg ser i alle fall to eksempler på hvordan ungdom lærer om seg selv i utdraget over. Jarvis sin tanke om læring som eksistensiell prosess er at det er et livslangt prosjekt. Det kan virke rart å tenke seg at eksistensielle prosesser kan skje i en enkelt øvelse. Allikevel mener jeg at det gir mening à tenke seg at man i øvelsen, og på konfirmasjonssamlingen, kan se spor av læring som eksistensiell prosess som en del av det livslange identitetsprosjektet til Jarvis.

Det ene eksemplet på læring som eksistensiell prosess er det Ungdom 2 sier. Ungdom 2 deler refleksjoner som vedkommende har gjort seg rundt eget liv og erfaringer, ved å si at han/hun mest sannsynligvis også ville vært kristen om foreldrene var norske. Ungdommen kobler sammen at den troen han/hun har, avhenger av kulturen og familien. Dette kan selvfølgelig være en tanke som ungdommen har gjort seg tidligere, men det kan også være spor av en prosess hvor ungdommen lærer om seg selv. Jarvis snakker om dette identitetsprosjektet som «learning to be me». I denne konfirmasjonssamlingen kan man kanskje kalle identitetsprosjektet for «learning to be a religious me».

Det andre er det Ungdom 3 sier. Ungdom 3 har stilt seg på svaralternativ D, og sier at «man kan jo ha det godt selv om man ikke tror på Gud». Har denne ungdommen lært om seg selv at han/hun har en mulig identitet som ikke-troende 
gjennom denne $\emptyset$ velsen? Har ungdommen funnet et ikke-religiøst selv, eller i alle fall funnet ut at det å ha det godt er viktigere enn en Gudstro? En interessant forskjell er at i motsetning til Ungdom 1 og Ungdom 2 som formulerte seg ut i fra førsteperson («jeg»-form), bruker denne ungdommen det upersonlige pronomenet «man». Innledningsvis hadde presten understreket viktigheten av å snakke ut ifra seg selv, og si «jeg tror/tenker», hva kan være grunnen til at denne ungdommen allikevel snakker med upersonlig pronomen? En mulighet er at ungdommen opplever at det å stå på svaralternativ D, og det å bevege seg mot en ikke-religiøsitet, er det som er minst akseptabelt på konfirmasjonsundervisningen. Interessant er det $\mathrm{i}$ alle fall å se at de to første ungdommene, som tydeligere hadde identitetsprosjektet «learning to be a religious me», brukte personlig pronomen, mens Ungdom 3, som kanskje hadde identitetsprosjektet «learning to be a non-religious me», valgte å bruke upersonlig pronomen.

I $\emptyset$ velsen har jeg sett at det er lagt opp til at ungdommene skal bruke sine egne erfaringer for å lære om seg selv i et helhetlig identitetsprosjekt, «learning to be me». At det er lagt opp til en slik type læring på konfirmasjonsundervisning, er ikke unikt for samlingen jeg var og observerte - se Johnsen $\mathrm{m}$. fl. sin analyse av hvordan deltagelse og identitetsutvikling vektlegges i konfirmantlæreverket «Nøkler til livet» fra 2015 (Johnsen mfl. 2018).

\section{Lytteøvelsen - ungdommenes respons}

I forlengelse av dette vil jeg også gå inn på en annen del av konfirmasjonsundervisningen for også her å ha fokus på ungdommene sin respons. Ungdommene gjorde da en lytteøvelse som ble introdusert på denne måten:

Prest: Jeg tenkte at hvis dere nå, hvis det er okei, å finne et vennlig menneske i rommet, så dere går sammen to og to så langt det går opp. $0 \mathrm{~g}$ så skal dere gjøre en liten kort lytteøvelse. og det er sånn at en snakker i ca ett minutt, og den andre sitter bare og lytter, og legger bort sine egne ting. For det er ofte når vi kan høre hva andre sier, så får vi lyst til å si noe eller lyst til å svare eller «sånn har jeg ... det skjedde med meg en gang», det kommer veldig fort sånn. Så bare sitt og lytt, og når den andre har snakket $i$ et minutt så sier jeg ifra, og da skal du prøve å gjenta innholdet i det den andre har sagt. Speile det tilbake.

Ungdom: Jeg er så dårlig på sånn (sier det lavt).

Prest: Det er ganske vanskelig. Men det er en veldig nyttig øvelse, å øve seg på å lytte. Det jeg hadde tenkt dere skulle si noe om ... Jeg tenkte litt på den filmen i stad, litt på det vi snakket om nå. «En gang jeg følte det ikke var plass til meg», eller at «jeg følte meg utenfor», «ikke bra nok» eller at «jeg hadde gjort noe som jeg angret $p \AA ̊ a »$. Velg noe innenfor det, noe som ikke var okei. En litt vanskelig opplevelse av utenforskap eller å ha gjort noe som jeg kjente at det var ikke greit, enten at jeg gjorde det selv eller at noen gjorde det mot meg. Hvis det er okei for dere å dele det. 
Etter at ungdommene var ferdig med å dele og lytte til hverandre, hadde de en samtale om hvordan øvelsen opplevdes. Dette er et utdrag av samtalen:

Prest: Okei, nå ncermer vi oss en avslutning, men før vi kommer dit, har jeg lyst til å høre om det er noen som vil dele. Hvordan var det å fortelle om noe som har vart litt vanskelig for deg?

Ungdom 1: Altså, jeg syns det var veldig rart at den personen skulle gjenta det. Fordi, for eksempel hvis det var vanskelig, så er det vanskelig å fortelle det, og så er det enda vanskeligere. Altså i tillegg til at det er vanskelig å fortelle det, så er det dobbelt så vanskelig at personen skal gjenta det igjen, hva som var vanskelig. Da blir det litt sånn, da føler du deg litt sånn mindre.

Prest: Mindre?

Ungdom 1: Ja, litt sånn. Vanskelig å forklare.

Prest: At det blir sterkere på en måte når det kommer tilbake fra en annen?

Ungdom 1: Ja. Da vet du at den andre personen hørte ordentlig godt etter ...

Prest: Men opplevde du det som krevende eller var det litt godt også, at den andre faktisk lyttet til deg?

Ungdom 1: Jeg gav beskjed om å ikke si det tilbake, jeg.

Prest: Ja, for du ville ikke høre det en gang til. (...)

Respons fra en annen ungdom:

Ungdom 2: Altså, jeg synes det var godt å få sagt noe, fordi jeg har snakket om det med flere av venninnene mine. Men det er sånn de er helt stille når jeg snakker, og så får jeg høre ting tilbake, og få deres meninger også. Men nå fikk jeg liksom si alt rett ut, og så når jeg fikk høre det tilbake, så hører jeg liksom hvor lite det egentlig er nå. Men jeg føler at jeg klager skikkelig over det og bare går rundt og tenker på det. Så nå har jeg sagt at jeg ikke skal snakke så mye om det fordi det er liksom så, ja.

Prest: Det satte det litt i perspektiv å få speilet på en måte?

Ungdom 2: Ja.

Prest: Fint.

Dette utdraget viser to eksempler på hva to ungdommer har lært gjennom $\emptyset$ velsen. Hva de lærte og erfarte gjennom $\emptyset$ velsen, er ganske forskjellig.

Ungdom 1 sier at han/hun syntes det var rart at noen skulle gjenta det som ble fortalt, siden de hadde fortalt noe som var vanskelig. Hva lærte ungdommen gjennom denne øvelsen, hvilken eksistensiell prosess ser man spor av? Ungdom 1 opplevde $\emptyset$ velsen som vanskelig, såpass vanskelig at ungdommen har valgt å ikke følge premissene for oppgaven, ved å be den andre om å ikke gjenta det som ble fortalt. Med tanke på læring som en eksistensiell prosess så har ungdommen 
hatt en eksistensiell erfaring av å føle seg «mindre». Av prestens respons til ungdommen kommer det fram at presten hadde intensjon om at denne $\emptyset$ velsen også skulle oppleves godt, ikke bare vanskelig og krevende, men ungdommens erfaring av $\emptyset$ velsen er ikke at den gjorde godt. Ungdom 1 gir på dette viset både $\emptyset$ velsen og presten motstand. For Ungdom 1 fungerte ikke denne $\emptyset v e l s e n$ slik $\emptyset$ velsen var intendert, men Ungdom 2 hadde en annen opplevelse av den samme øvelsen.

Ungdom 2 forteller at han/hun syntes det var godt å få snakke. Ungdommen sier at $\emptyset$ velsen har ført til at hun/han fikk satt det som ble delt, i perspektiv, og at hun/han innså «hvor lite det egentlig er nå». Ungdom 2 har hatt en eksistensiell erfaring av at $\emptyset$ velsen gjorde «godt». For Ungdom 2 fungerte $\emptyset v e l s e n$ i større grad slik den var intendert av presten. Ungdommen fulgte øvelsen og opplevde det som godt.

Den samme lytteøvelsen har gitt to ganske så forskjellige motsetningsfylte eksistensielle prosesser hos ungdommene. Den ene ungdommen erfarte $\emptyset$ velsen som vanskelig og følte seg «mindre», den andre ungdommen erfarte $\emptyset$ velsen som at den gjorde godt, og øvelsen førte til forandring ved at ungdommen fikk en erkjennelse av at det hun/han hadde opplevd, ikke var så stort. I Jarvis sin læringsteori er tanken at man trenger erfaringer som bringer med seg disharmoni og ubalanse for at læring skal skje gjennom en eksistensiell prosess, ved at uoverensstemmelsen skaper mulighet for forandring. Dette kan man se i eksemplene med de to ungdommene. De har hatt erfaringer som ser ut til å ha medført en viss ubalanse, noe som kan ha åpnet for en mulig forandrende eksistensiell prosess hos dem.

\section{DEL 2: LÆRING PÅ KOLLEKTIVT NIVÅ Praksisfellesskapet - deltagelse både metodisk og praktisk}

I teorien om læring som praksisfellesskap er det selve praksisene som man deltar i, det legges vekt på, ikke enkeltindividets kognitive læringsprosesser. Jeg vil naturlig nok analysere selve praksisene som ble utført i undervisningen, men det er også naturlig å se litt på hva som ble sagt (av presten), for også på det viset å se hvilke praksiser og praksisfellesskap som man prøver å lære ungdommene inn i. Øvelsen «Avgi din stemme med føttene» mener jeg er et godt eksempel for å se på sammenhengen mellom det det praktiske/fysiske og metodiske/ kognitive når læring skjer $\mathrm{i}$ et praksisfellesskap. Øvelsen kan man kanskje si ble introdusert og innøvd på to plan, både på det metodiske og praktiske. Før $\emptyset$ velsen satte i gang, var dette det første presten sa om øvelsen:

Prest: Nå skal vi gjøre en sånn dialogøvelse. Vi starter med noe som er veldig ufarlig. og det er at dere skal ta stilling. Så dere må, dere skal bruke beina sine til å gå, liksom 
stemme over hva dere liker best. Så de som liker nonstop, de går dit (peker til ene siden av rommet de bruker), og de som liker best melkesjokolade, de går dit (peker til andre siden. Det blir litt latter og uenighet om at nonstop også er melkesjokolade osv, men de deler seg).

Øvelsen blir presentert som en dialogøvelse, den går ut på at man skal ta stilling, og de skal starte med noe veldig ufarlig. Det ufarlige som det her tenkes på, er nok det man skal ta stilling til, som første omgang er om man foretrekker melkesjokolade eller nonstop. Men for å ta stilling må det en praksis til, ungdommene må med bena gå til den siden av rommet der deres standpunkt hører hjemme (nonstop på den ene siden, melkesjokolade på den andre). I innledning til dialog$\emptyset$ velsen kan man kanskje si at presten $\emptyset$ nsker å lære ungdommene inn i øvelsen på to måter. Fysisk ved at de må gå med bena, kognitivt ved at de må ta stilling. Etter spørsmålet om nonstop og melkesjokolade, må ungdommene ta stilling til lignende spørsmål om de foretrekker lakris eller smågodt, vann eller brus osv. Siden det de skal ta stilling til, regnes som ufarlig, er det vel kanskje selve det å faktisk ta stilling ved å bevege seg til en side av rommet, altså selve praksisen som blir øvd på. Undervisningen legger med andre ord opp til at ungdommene skal læres inn i en praksis med denne dialogøvelsen.

Etter å ha « $\phi v$ d på $\emptyset$ velsen» sier presten litt mer om hva som er viktig $\mathrm{i}$ selve øvelsen, når den nå skal bli litt vanskeligere (se sitat ovenfor). Presten sier for eksempel at det er viktig at alle tar utgangspunkt i seg selv, og kun representerer seg selv, for det er viktig når man jobber med dialog. Andre viktige retningslinjer er å ha respekt for hverandre, og ha tillit til at det som snakkes om, blir der. Presten nevner også at det å være åpen og frimodig er fint, for dialog handler om å dele, om å være sammen og prøve å forstå hverandre. Presten gir ungdommene noen retningslinjer som det er meningen at hele fellesskapet skal følge, det er læring på et kollektivt nivå. Prestens ord må forstås som en måte å lære ungdommene inn i dialog som metode og i et praksisfellesskap. Man læres altså inn i aktiviteten/praksisfellesskapet ved å delta både praktisk (ved å bevege seg) og metodisk (med retningslinjene som blir gitt for dialogen).

\section{Mulig med legitim perifer deltagelse?}

I Lave og Wenger sin teori om læring som praksisfellesskap er ideen at man læres inn i praksisen ved først å være i periferien, for så å bevege seg mot sentrum av praksisen. Man går fra å ha en mer perifer deltagelse til å bli en sentral deltager. I $\emptyset$ velsen «Avgi din stemme med føttene» under konfirmasjonssamlingen var alle ungdommene like nye i praksisen, alle var nykommere i tros- og livssynsdialogen. Hvordan kan $\emptyset$ velsen/praksisen beskrives med tanke på ulike deltagerposisjoner? Jeg vil si at i øvelsen var det ikke rom for en mer 
perifer deltagelse og en mer sentral deltagelse. Alle ungdommene måtte delta i like stor grad, og ved det være sentrale deltagere i praksisen. For å delta $\mathrm{i}$ praksisen tenker jeg at man faktisk måtte delta både kognitivt og fysisk. Fysisk ved gå til et av de fire hjørnene, og da samtidig kognitivt ved at de måtte ta stilling til spørsmålet ved å si seg enig (mest enig) med det svaralternativet man sto under. På dette viset måtte alle ungdommene delta i like stor grad i praksisfellesskapet. For å delta i praksisfellesskapet ble det stilt ganske høye krav til ungdommene da det kom til det kognitive. Spørsmålene de skulle ta stilling til, vil jeg si er forholdsvis vanskelige. Eksempler på spørsmålene er: «Tror vi alle på samme Gud?» og «Hva mener du er mest dominerende ved din tros- eller livsynstradisjon?». Ungdommene hadde fire svaralternativer å velge mellom, men ingen av disse alternativene var «vet ikke» eller et lignende svar. Det kan kanskje oppleves som store og vanskelige spørsmål å skulle ta stilling til. I tillegg til å måtte ta stilling ved å gå til et av svaralternativene, ble også ungdommene oppmuntret til å snakke etter at de hadde stilt seg opp:

Prest: Har alle funnet et sted nå? Da tenkte jeg liksom, da bare spør jeg noen av dere som er her da (henviser seg til de som står på B). Hvorfor valgte dere dette? Det er ikke som om noe er feil eller galt, nei riktig eller feil. Her er det bare om å gjøre å tenke gjennom hvorfor man tenker det man tenker.

Ved at presten henvendte seg til ungdommene på den måten, var det flere av ungdommene som frivillig tok ordet og delte med de andre hvorfor de sto der de sto. Det hendte også at presten direkte henvendte seg til en ungdom, og kunne da få svar som «jeg vet ikke», eller «jeg er ikke helt sikker». Dette understreker at det ikke var rom for en legitim perifer deltagelse i øvelsen. Legitim perifer deltagelse vil si en deltagelse der det er lagt til rette for å kunne gjøre grunnleggende oppgaver for praksisfellesskapet, men med redusert risiko. Det skal i tillegg til å være deltagelse i grunnleggende oppgaver være et element av ikke-deltagelse. Til forskjell fra sentrale deltagere skal legitime perifere deltagere ikke ha ansvar for å løse den felles oppgaven for praksisfellesskapet (Johnsen 2014:157). I øvelsen «Avgi din stemme med føttene» i konfirmasjonssamlingen var det ikke lagt til rette for å kunne delta på grunnleggende oppgaver i praksisen, men med redusert risiko, ved for eksempel et element av ikke-deltagelse. Hadde det for eksempel vært et «vet ikke»-svaralternativ, eller hadde ungdommene visst at de kun trengte å snakke frivillig og ikke blitt utfordret på å forklare «hvorfor man tenker det man tenker», kunne dette vært måter å delta på med redusert risiko. Slik øvelsen var, vil jeg si at dette praksisfellesskapet kun gav rom til at man måtte være en sentral deltager.

Denne $\emptyset$ velsen som praksisfellesskap gav altså ikke rom for å delta med 
noen redusert risiko. Jeg vil si at $\emptyset$ velsen både gjennom vanskelighetsgrad av spørsmålene og gjennom instruksjonen for $\emptyset$ velsen/dialogen gitt av presten, la opp til en høy risiko fra ungdommenes side. I prestens instruksjon ble det lagt noen retningslinjer for dialogen/øvelsen. Ungdommene ble bedt om à ta utgangspunkt i seg selv, tørre å være frimodige, og være åpne og dele. De som det derimot ikke var høy risiko for, var presten og ungdomslederen som gjennomførte øvelsen, de trengte ikke å ta stilling til spørsmålene eller dele hva de tenkte, med ungdommene. I analysen av konfirmantboken Nøkler til livet legges det vekt på at boken tilbyr et konfirmantopplegg der svarene ikke er gitt fra før, men hvor opplegget legger opp til at konfirmantene blir bedt om å stadig ta stilling, og bestemme hva som er meningen i deres liv. Johnsen mfl. skriver at: «Det kan innebære å overlate en veldig stor oppgave til hver enkelt konfirmant, og at kristen tro gjøres til et individuelt anliggende» (Johnsen mfl. 2018:75-76). Det samme vil jeg si om «Avgi din stemme med føttene»-øvelsen som praksisfellesskap i konfirmasjonssamlingen. Øvelsen gir hver ungdom en individuell, stor og krevende oppgave.

\section{DEL 3: LÆRING PÅ INSTITUSJONELT NIVÅ Gjestene som ekspansjon}

Engeström studerer arbeidsplasser eller institusjoner som er i en endringsprosess og prøver å finne nye løsninger på ting de ikke har svaret på på forhånd. Slik sett egner Engeströms teori seg godt for å analysere konfirmasjonssamlingen på et institusjonelt nivå. For $i$ analysen vil jeg vise at konfirmasjonssamlingen jeg observerte, uten tvil viser en kirke som på grunn av et endret flerreligiøst samfunn prøver å være kirke på en ny måte. Jeg vil også vise at dette skjer ved ekspansjon av konfirmantundervisningen. Den mest synlige og viktigste utvidelsen eller ekspansjonen i konfirmasjonssamlingen var gjestene som deltok på samlingen. Konfirmantene var blitt utfordret til å ta med en venn med en annen tro eller et annet livssyn til samlingen. Det å ha inn andre enn konfirmantene i konfirmasjonsundervisningen er en tydelig, fysisk ekspansjon. Konfirmasjonssamlingen kunne ha hatt dialog om tro og livssyn uten at det var annerledestroende til stede på undervisningen, men med gjestene med annen tro blir det en interreligiøs dialog. Ekspansjonen av å ha gjestene med på samlingen og av den interreligøse tros- og livssynsdialogen gjør seg synlig flere plasser i konfirmasjonssamlingen.

\section{Fastepraksis - gjestene som en revitalisering}

I $\emptyset$ velsen «Avgi din stemme med føttene» handlet det siste spørsmålet om fastepraksis, om hvorvidt fastepraksis var viktig i egen tros- eller livsynstradisjon. De foregående spørsmålene i $\emptyset$ velsen hadde presten funnet ferdig formulert i «Sier vi»-heftet («Sier vi» 2018:112-113), men dette siste spørsmålet om 
fastepraksis hadde presten selv formulert for å bruke på denne konfirmasjonssamlingen. Her er et utdrag av $\emptyset$ velsen hvor noen av ungdommene delte sine erfaringer omkring fastepraksis.

Prest: Men for dere er det viktig? (til de som står i A-hjørnet) Har dere lyst til å dele litt om det?

Ungdom gjest 1: Jeg kan starte da. Fordi jeg er muslim da, og det er jo en av de viktigste $i$ troen da, av de fem søylene, tredje eller fjerde søyle. Så det er jo en av de viktigste for å tro på religionen da.

Prest: Ja, en veldig viktig praksis.

Ungdom gjest 1: Ja.

Prest: Har du fastet selv?

Ungdom gjest 1: Ja, jeg har prøvd.

Prest: Hvordan var det?

Ungdom gjest 1: Det er jo vanskelig da, men etter hvert blir man vant til det.

Prest: Er det noen andre her som har lyst til å dele? Ja? (gir ordet til en annen på A-hjørnet)

Ungdom: Altså for meg i hvert fall, jeg prøvde skikkelig ... (utydelig hva som ble sagt).

Det var kjempevanskelig, altså.

Prest: Hva var det du gjorde da?

Ungdom: Altså, jeg gjorde drill. Så hadde jeg bestemt meg siden jeg trengte ekstra øving folte jeg, så jeg bestemte meg for å drille hver dag i minst en halvtime til en time. [...]

Prest: Da ble det i hvert fall klart for alle at faste det kan voere ulike ting, ikke sant? [...] Men hadde du lyst til a fortelle?

Ungdom gjest 2: Jo, for hos oss så er det vanlig at, eller at man skal ikke spise kjøtt den dagen man drar til tempelet. Jeg tror det har noe med at i religionen vår er dyr ofte med, og det blir ofte sett på som noe hellig som når ... (litt utydelig). Så da er det sånn respekt a ikke spise kjøtt da, for det er jo et liv.

Prest: Ja, ikke sant.

Ungdom gjest 2: $0 \mathrm{~g}$ så er det noen som ikke spiser kjøtt i det hele tatt da. Men det spørs hvor religiøs man er. Ikke jeg da (litt latter fra ungdommene).

Prest: Og så er det også noen som velger å vcere vegetarianere, å aldri spise kjøtt?

Ungdom gjest 2: Ja, men det er sånn presten, det er ofte de som aldri spiser kjøtt.

Prest: Og så når jeg besøker tempelet. Så serverer de aldri kjøtt i tempelet.

Ungdom gjest 2: Nei, det er uhellig, eller ... ja.

Prest: Det som jeg tenkte jeg skulle si litt sånn kort da om kristen faste, siden kanskje ikke alle kjenner det så godt. Tradisjonelt så handlet det om å ikke spise kjøtt faktisk, og for mange gjør det fortsatt det.

Utdraget viser tre ungdommer, tilhørende tre forskjellige religioner, som deler sine erfaringer med fastepraksis. Utdraget viser at spørsmålet fungerte godt for 
å vise at fastepraksis kan være ulike ting, og er å finne i flere religioner, noe også presten påpeker. Dette ble konkret synlig både ved det de tre ungdommene delte, og ved at presten tok samtalen videre og snakket om den kristne fasten. På dette viset ble det synliggjort at fastepraksis kan utøves på forskjellige måter samtidig som det kobles opp som noe felles i flere religioner. Konfirmasjonssamlingen løftes til ikke bare å være en tradisjonell konfirmasjonsundervisning i kristen tro og praksis, men til å handle om det større bildet som går på tvers av religioner. I tillegg til at fastepraksis som spørsmål og tema i samlingen făr fram at det finnes ting som er felles på tvers av religioner, så er det også andre aspekter som gjør seg synlig i denne ekspansjonen som jeg videre vil komme inn på.

Engeström skriver om hvordan motsigelser er en kilde til forandring og utvikling. Motsigelser må ikke forstås som problemer eller konflikt. Når en aktivitet (eller et aktivitets-system som Engeström kaller det) tar til seg et nytt element fra utsiden, så fører det ofte til at motsigelsene forsterkes ved at noen av de gamle elementene (som for eksempel reglene for aktiviteten) kolliderer med det nye elementet. Engeström skriver at slike motsigelser genererer forstyrrelser, samtidig som det skaper innovasjon som kan forandre aktiviteten (Engeström 2009:57). Dette kan brukes til å analysere materialet fra konfirmasjonsundervisningen. Som jeg alt har vært inne på, så kan gjestene som deltar i samlingen, forstås som en konkret ekspansjon. Gjestene er et nytt element som kommer fra utsiden og som aktiviteten tar til seg. Som Engeström skriver, så kan det nye elementet føre til motsigelser og «kollidere» med gamle elementer (slik som regler for aktiviteten) som igjen kan føre til endring og innovasjon. Dette kan være interessant å unders $\emptyset$ ke med tanke på eksempelet om faste og fastepraksis. Gjestene på samlingen hadde et mer aktivt forhold til fastepraksis enn hva de aller fleste av konfirmantene hadde. Det var bare én konfirmant som fortalte om et fors $\emptyset \mathrm{k}$ han/hun hadde gjort på å faste (ungdommen som drillet $\mathrm{i}$ utdraget over), ellers virket det ikke som om andre av konfirmantene hadde noe forhold til fastepraksis (i alle fall var det ingen som sa noe om det). Gjestenes aktive forhold til faste kan sies å skape en $\emptyset$ kt motsigelse til den (kristne) fasten som konfirmantene kjente til, dette kan forstås som reglene eller de gamle elementene. Men denne motsigelsen og forstyrrelsen for den kristne, $i$ hovedsak ikke-eksisterende, fastepraksisen opplevde jeg at førte til en fornyelse av den kristne fasten. Gjestenes nye element inn i aktiviteten kan kanskje føre til revitalisering og $\emptyset \mathrm{kt}$ aktualitet av den kristne fasten. På dette viset fikk gjestene som var til stede, nærmest en egen funksjon i samlingen ved at de bidrog til å gjøre fasten til en mer levende praksis for konfirmantene. Også for presten, som skulle lære ungdommene om den kristne fasten, opplevde jeg gjestenes bidrag inn i samtalen om fastepraksis som en hjelp for presten til å gjøre fasten mer aktuell for konfirmantene. 


\section{KONKLUSJONER}

Hvordan lærer ungdom tros- og livssynsdialog på en konfirmasjonssamling? I analysen har jeg flere eksempler på dette på hvert av de tre nivåene.

På individuelt nivå viste analysen at ungdommene lærte om seg selv (learning to be me), og man så spor av eksistensielle prosesser, som kan beskrives som endringsprosesser. Det ungdommene lærte om seg selv, var motsetningsfylt, og varierte i stor grad. Analysen viste at den samme øvelsen kunne gi ulike erfaringer hos ungdommene. Erfaringer av disharmoni og ubalanse førte til forandring og til læring som mulig eksistensiell prosess.

På kollektivt nivå var hovedfunnet $\mathrm{i}$ analysen min at deler av konfirmasjonsundervisningen krevde at alle ungdommene måtte ta stilling til utfordrende påstander om tro og livssyn. Det ble da ikke lagt til rette for at ungdommene kunne velge deltagerposisjoner med ulik grad av personlig risiko.

På institusjonelt nivå så jeg at læringen skjedde gjennom ekspansjon. Nye elementer ble tatt inn i praksisen (konfirmasjonssamlingen). Denne ekspansjonen gav $\emptyset$ kte motsigelser til den eksisterende praksisen/de gamle elementene. Den $\emptyset$ kte motsigelsen og forstyrrelsen førte samtidig til en endringsprosess $i$ form av fornyelse.

Ut i fra analysen vil jeg argumentere for at tros- og livssynsdialog, i den formen vi har sett her, legger til rette for at læring skjer ved å ta i bruk motsetningsog spenningsfylte praksiser. Læring skjer gjennom nye kollektive erfaringer som muligens fører til endringsprosesser både hos hver enkelt ungdom og som institusjon. Analysen på kollektivt nivå viser at selv om mye læring skjer i disse praksisene, så har praksisene høy risiko ved at de krever mye av ungdommene og ikke gir rom for å delta på andre vis enn ved å være en sentral akt $\emptyset$ r.

\section{LitTERATUR}

Afdal, Geir. 2013. Religion som bevegelse. Lœring, kunnskap og mediering. Oslo: Universitetsforlaget.

Engeström, Yrjö. 2009. «Expansive learning. Toward an activity-theoretical reconceptualization» i Illeris, K. red Contemporary Theories and Learning. Learning theorists ... in their own words. Abingdon: Routledge, s 53-73.

«Homo-hore-jøde-terrorist-svarting» - sier vi. Et ressursmateriell om antisemittisme, muslimfiendtlighet og rasisme mot rom til bruki Den norske kirke. 2018. 2. utg. Utarbeidet av Kirkelig Dialogsenter i Oslo. Østfold trykkeri: Utgitt av Mellomkirkelig råd.

Jarvis, Peter. 2009. «Learning to be a person in society. Learning to be me» i Illeris, K. red. Contemporary Theories of Learning. Learning theorists ... in their own words. Abingdon: Routledge, s 21-34. 
Johnsen, Elisabeth Tveito. 2014. «Gudstjenestelæring gjennom deltakelse» i Hellemo, G. red. Gudstjeneste på ny. Oslo: Universitetsforlaget, s 151-179.

Johnsen, Elisabeth Tveito, Kirkemo, Eva, Mysen, Solveig Julie og Gillebo, Mathias. 2018. «Fra katekisme til liberal pietisme. Konfirmantbøker anno 2015» i Prismet, 69 (1), s 69-84.

Wenger, Etienne. 2009. «A social theory of learning» i Illeris, K. red. Contemporary Theories of Learning. Learning theorists ... in their own words. Abingdon: Routledge, $\mathrm{s}$ 209-218. 